\title{
Evaluation of Soil Fertility Indices of Freshwater Irrigated Soils in Mexico Across Different Climatic Regions
}

\author{
I. Nikolskii-Gavrilov ${ }^{1}$, I. P. Aidarov ${ }^{2}$, C. Landeros-Sanchez ${ }^{1}$, S. Herrera-Gomez ${ }^{1} \&$ O. Bakhlaeva-Egorova ${ }^{1}$ \\ ${ }^{1}$ Colegio de Postgraduados, Campus Veracruz, México \\ ${ }^{2}$ Russian Academy of Agricultural Sciences, Krzhizhanovski str., Moscow, Russia \\ Correspondence: C. Landeros-Sanchez, Colegio de Postgraduados, Campus Veracruz, México. E-mail: \\ clandero@colpos.mx
}

$\begin{aligned} & \text { Received: February 28, } 2014 \\ & \text { Accepted: March 25, } 2014 \quad \text { Online Published: May 15, } 2014 \\ & \text { doi:10.5539/jas.v6n6p98 }\end{aligned}$ URL: http://dx.doi.org/10.5539/jas.v6n6p98

\begin{abstract}
Irrigation has different impacts on soils. The most studied negative impacts are related with salinity, sodicity or soil contamination because of poor irrigation water quality or rising water tables. It is assumed that with suitable water quality the impact of irrigation on soil is positive. However, there are publications showing that under certain conditions long-term freshwater irrigation may cause soil fertility deterioration. Therefore a hypothesis has appeared that some Mexican soils may also be degraded. The objective of our study was to compare some properties of agricultural soils irrigated for more than 30 years with freshwater with non-irrigated virgin soils in different climatic zones. The principle agricultural crops studied were corn and wheat. The impact of furrow and border strip irrigation on soils were positive under arid climatic conditions, but in semi-arid, semi-humid and humid conditions irrigation gradually caused deterioration of soil fertility because of annual leaching of organic matter and exchangeable calcium. Comparison of the same properties of rainfed agricultural soils for the same crops and virgin soil properties did not show significant differences. Thus, irrigation itself can induce changes in soil fertility. Therefore, in semi-arid, semi-humid and humid conditions of Mexico it is appropriate to reduce irrigation water losses. Under humid conditions it is recommended to increase runoff using surface drainage in irrigated and rainfed lands and to improve irrigation technologies. These measures can conserve soil fertility, improve efficiency of water and land resource use, reduce water consumption, increase agricultural productivity, profitability and sustainability over the long-term.
\end{abstract}

Keywords: fertility index, irrigation water quality, soil degradation, radiative climatic index, arid and humid zones, soil properties, percolation

\section{Introduction}

Traditionally, irrigation water requirements are determined based on the needs of agricultural crops and on the availability and quality of water. Selection of irrigation technology depends on the profitability of agricultural crops, experience and economic state of farmers, availability of water, topographic and climatic conditions of irrigated land and soil physical properties. Irrigation increases agricultural productivity and affects soil properties, and may increase soil fertility, but can reduce it as well. The positive effect of soil irrigation is related to increased soil moisture, resulting in increased microbiological and macro-biological activities in the soil and the accumulation of organic matter (Aidarov, 1985; Baldock et al., 2000; Schjonning et al., 2004; Oriola, 2005). Negative effects of soil irrigation are usually associated with using poor quality water (e.g. saltwater, treated or untreated sewage water), salinity, sodicity or soil contamination, as well as soil erosion. There are different recommendations for reducing the risk of soil and plant contamination to prevent or reclaim soil salinity and sodicity of irrigated lands (Aidarov, 1985; Skaggs \& van Shilfgaarde, 1999; Artigao et al., 2002; Redly \& Utkaeva, 2005; Alguacil del Mar et al., 2012).

Irrigation with suitable quality water, as a rule, improves soil fertility. However, there are published studies on long-term freshwater irrigation causing gradual deterioration of soil fertility over several decades, even if there is no hydraulic soil erosion, or soil salinity or sodicity. For example, freshwater irrigation of wheat, corn and other crops on Chernozem soils (FAO, 2006) with 6-9\% organic matter content, slopes less than $1 \%$ in the steppe zone, and under semi-arid and semi-humid climates in Russia over 20 years caused a 1-2\% loss of organic matter; a 20\% reduction of exchangeable calcium content due to its deficit in the soil, and a 1.2-2-fold increase of exchangeable 
sodium and magnesium. The irrigation water had $E C=0.00025-0.0008 \mathrm{dS} \mathrm{m}^{-1}, S A R=1-1.5$ and $E C / S A R=$ 0.0002-0.0005 (Aidarov, 1985; Aidarov et al., 2012). The loss of irrigation water through soil percolation was between $30-40 \%$ of the annual net irrigation depth.

Mekonnen et al. (2011) pointed out that furrow and border strip irrigation in Ethiopia over 20-30 years caused a reduction of organic matter by $1-2 \%$ in different plots, a slight accumulation of exchangeable magnesium, and an accumulation of available phosphorus in comparison with non-irrigated soils. The change in exchangeable calcium and sodium varied from reduction to accumulation. A reduction in infiltration rate (around 30\%) also was observed. The investigation was conducted in semi-humid and humid climatic zones with mean annual temperatures of $20-23^{\circ} \mathrm{C}$, precipitation from 850 to $2050 \mathrm{~mm}$, deep soils containing alisols, fulvisols, vertisols and cambisols with more than 30\% clay and more than $2 \mathrm{~m}$ deep, altitudes of 1700-2200 masl, lands with relatively low slopes ( $<5 \%)$ and with crops such as corn, wheat, barley and some vegetables. Irrigation water had a $p H=7-8$ and electrical conductivity of $0.0018-0.0026 \mathrm{dS} \mathrm{m}^{-1}$.

The publications mentioned above show that freshwater irrigation can negatively impact soil fertility and that the process of change in soil agrochemical properties is rather slow and continues over decades.

The total irrigated agricultural area in Mexico is $6.5^{*} 10^{6}$ ha, with $3.5^{*} 10^{6}$ ha in 112 irrigation districts, most of them established during the $1950-1960$ s and $3^{*} 10^{6}$ ha in 39492 irrigation units created over the last 30 years. The primary irrigation systems are located in arid and semi-arid zones in the northern and central parts of the country, and were created during the mid-20th century. Irrigation is applied at altitudes from 0 to 2500 masl. The principle source of irrigation is surface water from reservoirs located mostly in mountains and supplying nearly $85 \%$ of the total irrigated area. Around $90 \%$ of the total irrigated area is irrigated by furrows and border strips.

The quality of surface water in most cases is suitable for irrigation purposes (De la Pena-De la Torre and Llerena-Villalpando, 2001). The typical cation and anion content $(\mathrm{pH}, \mathrm{cmol} / \mathrm{L})$, electrical conductivity $\left(E C, \mathrm{dS} \mathrm{m}^{-1}\right)$ and relative sodium content $\left(S A R,\left[(\mathrm{cmol} / \mathrm{L})^{1 / 2}\right]\right.$ are: $\mathrm{Ca}^{2+}=0.1-1, \mathrm{Na}^{+}=0.1-0.5, \mathrm{Mg}^{2+}=0.02-0.2, \mathrm{~K}^{+}=0.02-0.05$, $\mathrm{Cl}^{-}=0.1-0.4, \mathrm{SO}_{4}{ }^{2-}=0.1-0.2, \mathrm{HCO}_{3}{ }^{-}=0.1-0.2, \mathrm{CO}_{3}{ }^{2-}=0-0.005, \mathrm{pH}=6-8, \mathrm{EC}=0.002-0.004, \mathrm{SAR}=$ 0.2-0.3(CONAGUA, 2009; De la Pena-De la Torre and Llerena-Villalpando, 2001).

Although water and wind erosion are widespread in Mexico, in accordance with SEMARNAT-CP (2002) and SEMARNAT (2005), the water erosion on irrigated and rain-fed lands with slopes less than $1 \%$ is not typical. Given such slopes, only less than $0.04 \%$ of all irrigated lands and less than $4 \%$ of rain-fed lands are affected by hydraulic erosion. Wind erosion on these lands also is not typical; less than $2 \%$ of irrigated lands and less than $6 \%$ of rain-fed lands are affected by wind erosion (Semarnat-Cp, 2002; Semarnat, 2005).

The primary irrigated areas are located in the arid and semi-arid zones of Mexico, where $I>2$ (Figure 1). However, irrigation is also applied in semi-humid and humid tropical zones. In semi-arid and arid regions, irrigation is applied throughout the year where water availability is sufficient and where air temperatures are favorable. In areas with colder climates or with a deficit of water, irrigation is applied once a year during one growing season. In the humid tropical regions, irrigation is applied during the dry season (February to June), when the potential evapotranspiration is 3-4 times more than precipitation.

High soil salinity or sodicity are not typical for irrigated lands in Mexico. According to De la Pena (1996), this problem occurs in areas not exceeding $10 \%$ of all irrigated lands. It occurs primarily in the northern arid part of the country. All irrigated lands analyzed in the present study do not have soil salinity or sodicity problems (De la Pena, 1996). The hypothesis was that irrigation in some climatic zones of Mexico may cause soil degradation even if there is no hydraulic surface soil erosion. The objective of this study was to compare some properties of agricultural soils irrigated for more than 30 years with freshwater with non-irrigated virgin soils in different climatic zones.

\section{Material and Methods}

To observe consistent patterns of long-term changes in soil fertility related with freshwater irrigation, average values of soil properties from corn and wheat systems were compared with the same regional properties for natural soils not used for agriculture in different climatic zones of Mexico. The approach by Volobuyev (1974) was applied in this study which is based on quantitative models for assessing the role of solar energy and water in different processes of soil genesis including evapotranspiration, photosynthesis, formation of organic matter, physical and chemical weathering, and migration of substances in the soil profile. According to Volobuyev's concept, some regional chemical and physical properties of virgin soils inside geomorphologically homogeneous soil groups with similar genesis depend on mean annual climatic conditions expressed by the climatic index, $I$, (some authors call this index as the radiative index of dryness) (Volobuyev, 1974; Aidarov, 1985; Nikol'skii et al., 
2010). This concept quantitatively expresses the Geographical Law of Soil Zonality (Dokuchaev, 1899; Jenny, 1941; Grigoriev, 1954; Buol et al., 1990). Our work assessed soil fertility change from long-term freshwater furrow and border strip irrigation in different climatic zones of Mexico by comparing properties of agricultural soils irrigated for more than 30 years to those that were non-irrigated or unused virgin agriculture soils inside geomorphologically homogeneous soil groups located under the same climatic conditions and in relatively flat lands (with slopes less than 1\%). The principle agricultural crops on analyzed irrigated lands were corn and wheat.

The distribution of irrigated lands together with the distribution of principle climatic zones is shown in Figure 1. The climatic zones are characterized by means of a dimensionless climatic index (I) (Volobuev, 1974; Budyko, 1977; Koster \& Suarez, 1999):

$$
I=R_{\text {nat }} /(L * P r)
$$

where $R_{\text {nat }}$ is the mean annual net radiation ( $\mathrm{KJ} \mathrm{m}^{-2}$ per year), $L$ is the latent heat of evaporation equal to 2.51 $\mathrm{KJ} /\left(\mathrm{m}^{2} \mathrm{~mm}\right), \operatorname{Pr}$ is the mean annual precipitation (mm per year). Values of $I<1$ correspond to tropical humid conditions where $1500 \leq \operatorname{Pr}<3500 \mathrm{~mm}$ per year; $1 \leq I<2$ to semi-humid regions where $1000 \leq \operatorname{Pr}<1500 \mathrm{~mm} ; 2$ $\leq I<3.5$ to semi-arid where $350 \leq P r<1000 \mathrm{~mm}$ and $I>3.5$ to arid conditions where $P r \leq 100 \mathrm{~mm}$. The mean annual temperature over the analyzed area is around $20^{\circ} \mathrm{C}$, although it varies from 10 to $25^{\circ} \mathrm{C}$.

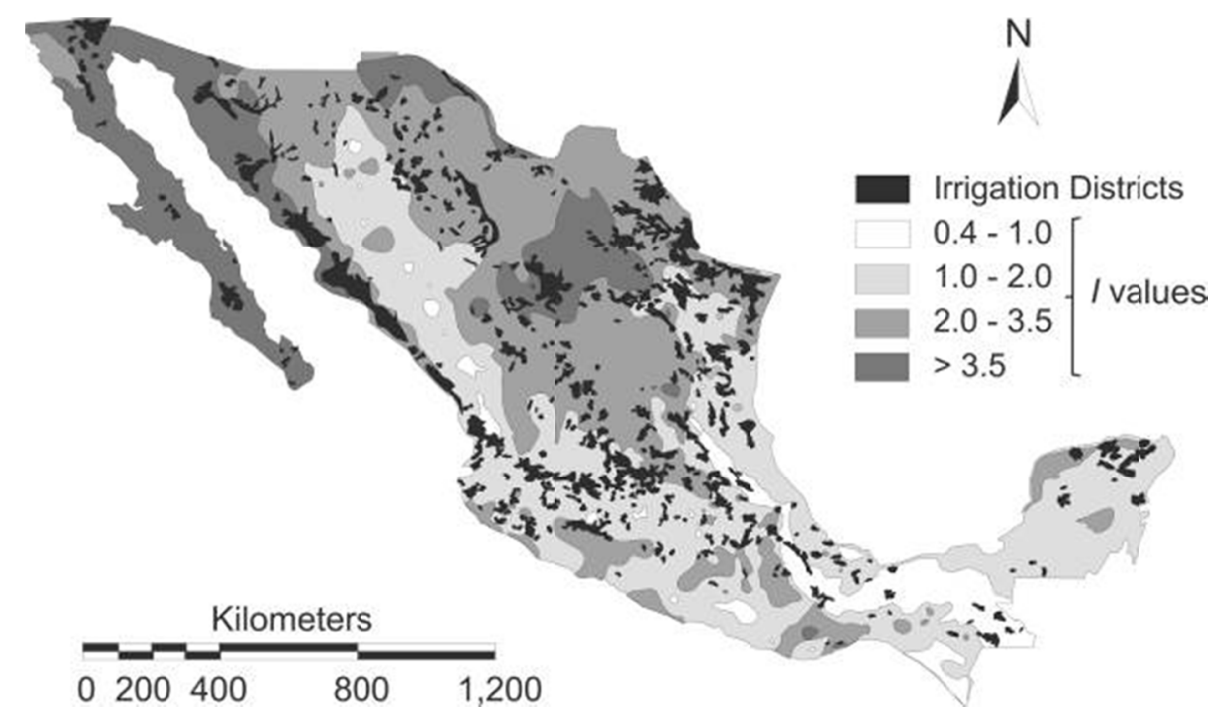

Figure 1. Distribution of irrigated lands and main climatic zones in Mexico. The climatic zones are defined by the climatic index $I$ calculated by the expression (1): $I=0.4-1$ correspond to humid regions; $1-2$ semi-humid; 2-3.5 semi-arid; and $>3.5$ arid zones

The set of digital geographical maps of Mexico (topographic, climatic, soil, hydrogeological, vegetation, and land use) with scales 1: 50000 and 1:250000, and the soil databases from INEGI (2004), CONAGUA (2012), Semarnat (2005) and Krasilnikov et al. (2011), as well the climatic database from IMTA (2006), were used to determine regularities in the distribution of modal values of some irrigated and virgin soil properties, $f$, depending on the climatic index, $I$.

Areas with deep water tables (more than $5 \mathrm{~m}$ deep) and with slopes less than $1 \%$ were selected using GIS (ArcInfo 8.01 and ArcView 3.2). Slopes less than 1\% correspond to most irrigated lands and are typical for $45 \%$ of the total agricultural area, including rainfed lands. A total of 2378 soil profiles were selected from the available databases. The mean annual climatic index, $I$, was determined for each geo-referenced site with known soil properties using the available data on long-term climate observations in the existing network of meteorological stations. For the interpolation of climatic data, the program SURFER 8 (2000) was used, considering topography and the coordinates of meteorological stations.

Plots with irrigated corn and wheat as the primary food crops in Mexico were selected for investigation. These crops occupy roughly $20 \%$ of the total irrigated lands in the country. The total area of the selected irrigated plots is approximately $8^{*} 10^{5}$ ha in 20 irrigation districts and units located primarily in the states of Sonora, Jalisco, 
Guanajuato, San Luis Potosi, Zacatecas, Tlaxcala, Mexico and Veracruz. These states are major producers of these crops.

The soils are mainly Phaeozems in the semi-arid and semi-humid regions of the central part of the country(climatic index $1 \leq I<3.5$ ), Xerosols (or Calcisols according to FAO, 2006) and Rendzinas (Leptosols), Kastanozems in the arid and semi-arid zones of the central and northern regions $(2.5<I<8)$, and Luvisols and Vertisols (FAO, 2006) in the temperate and tropical humid regions in the central and southeastern part of the country $(I<2)$ (INEGI, 2004; Krasilnikov et al., 2011). Soil depth usually exceeds $1.5 \mathrm{~m}$, and all soils have good agricultural potential, high saturation of exchangeable bases and the presence of stable aggregates. The Rendzinas have a predominance of calcium cations in an adsorbed complex. Vertisols are clay-based and characterized by expansion-contraction and cracking as a result of annual wetting and drying of the soil. More information about properties of these soils can be found in INEGI (1988) and Krasilnikov et al. (2011), as well as in the Results and Discussion of the present paper.

We analyzed and compared the distribution of modal values of virgin and irrigated soil properties, $f$, in the $0-20 \mathrm{~cm}$ layer depending on the climatic index, $I$. In order to establish a relationship between soil fertility and climatic index, $I$, we analyzed soil organic matter content ( $S O M$ ), soil phosphorus available for crops $(P)$, exchangeable $\mathrm{K}, \mathrm{Ca}, \mathrm{Na}$ and $M g, p H\left(p H_{\text {water }}\right)$, cation exchange capacity $(C E C)$, and the dimensionless integral soil fertility index, $F$, which was calculated using $O M, P, K$ and $p H$ (Pegov and Khomyakov, 1991; Nikol'skii et al., 2010):

$$
F=0.46\left(O M / O M_{\max }\right)+0.28 \sqrt{\left(P / P_{\max }\right)\left(K / K_{\max }\right)}+0.26 \exp \{-[(p H-6) / 2]\}^{2}
$$

where $F$ varies from 0 (for completely degraded soils) to 1 (the maximum possible level of soil fertility studied in Mexico); $O M_{\max }, P_{\max }$, and $K_{\max }$ are maximum values of these properties among analyzed soil groups.

The original formula for calculating $F$ (Pegov \& Khomyakov, 1991) includes the nitrogen available for crops. Due to absence of this information in Mexican databases, this value in (2) is indirectly taken into account in the coefficient associated with organic matter content.

To establish the relationship $f(I)$, values of soil properties were selected from the existing databases. Then, for each group of sites located in areas with similar intervals of $I$ (with step 0.5 for $I$ from 0.25 to 4 , and 1.0 for $I$ more than 4) average values of each property were determined. On average, 80-100 values for each property of virgin soils and 10-30 values for irrigated soils were obtained for each selected interval of change in $I$. We assumed that within the relatively small intervals of change in $I$ it is possible to ignore the dependence of each property, $f$, on the climatic index, $I$. Then each value $f$ was divided by its mean arithmetic value within each of the selected intervals of $I$. The combination of all normalized values of $f$ was considered statistically homogeneous and their statistical distributions were determined. Statistical analyses showed that the distribution of analyzed soil properties is close to lognormal. Therefore, the modal values of each property (not the mean arithmetic values) inside the selected $I$ intervals were determined, as well as the confidence intervals with $95 \%$ probability (Venables \& Ripley, 1997). Then, using the program CurveExpert 1.3 (Hyams, 2012), the graphs of modal values of soil properties, $f$, depending on the climate index, $I$, for virgin and irrigated soils were obtained.

\section{Results and Discussion}

Graphs of the relationships between the modal regional properties of virgin and irrigated soils in Mexico and the climatic index $I$ are shown in Figures 2 and 3 (95\% confidence intervals included).

The intervals of change in mean annual values of the climatic index (I), precipitation (Pr), potential evapotranspiration $(E T)$, and net irrigation depth $(I r)$ for selected crops together with accompanying plants inside the annual crop rotation are (Imta, 2006; CONAGUA, 2008, 2009):

$$
\begin{array}{llll}
1 \geq I>0.4 & 1500 \leq \operatorname{Pr}<3500 \mathrm{~mm} & E T=800-950 \mathrm{~mm} & I r=600-900 \mathrm{~mm} \\
2 \geq I>1 & 1000 \leq \operatorname{Pr}<1500 \mathrm{~mm} & E T=850-1150 \mathrm{~mm} & I r=750-1050 \mathrm{~mm} \\
3.5 \geq I>2 & 350 \leq \operatorname{Pr}<1000 \mathrm{~mm} & E T=1000-1300 \mathrm{~mm} & I r=900-1100 \mathrm{~mm} \\
8 \geq I>3.5 & 150 \leq \operatorname{Pr}<350 \mathrm{~mm} & E T=1300-1500 \mathrm{~mm} & I r=1000-1200 \mathrm{~mm}
\end{array}
$$

The distribution graphs of exchangeable potassium for virgin and irrigated soils are virtually identical. The $p H$ values for irrigated soils are slightly less than for virgin soils in all climatic zones. The distribution of organic matter content, available phosphorus and the integral soil fertility index are very different (Figure 2). Organic matter content in irrigated soils from central regions of the country with semi-arid, semi-humid and humid climates $(0.4<I \leq 3.5)$ is significantly less than in virgin soils. Another observation is that in arid regions $(I>3.5)$ irrigated soils have nearly twice the content of organic matter than virgin soils. 

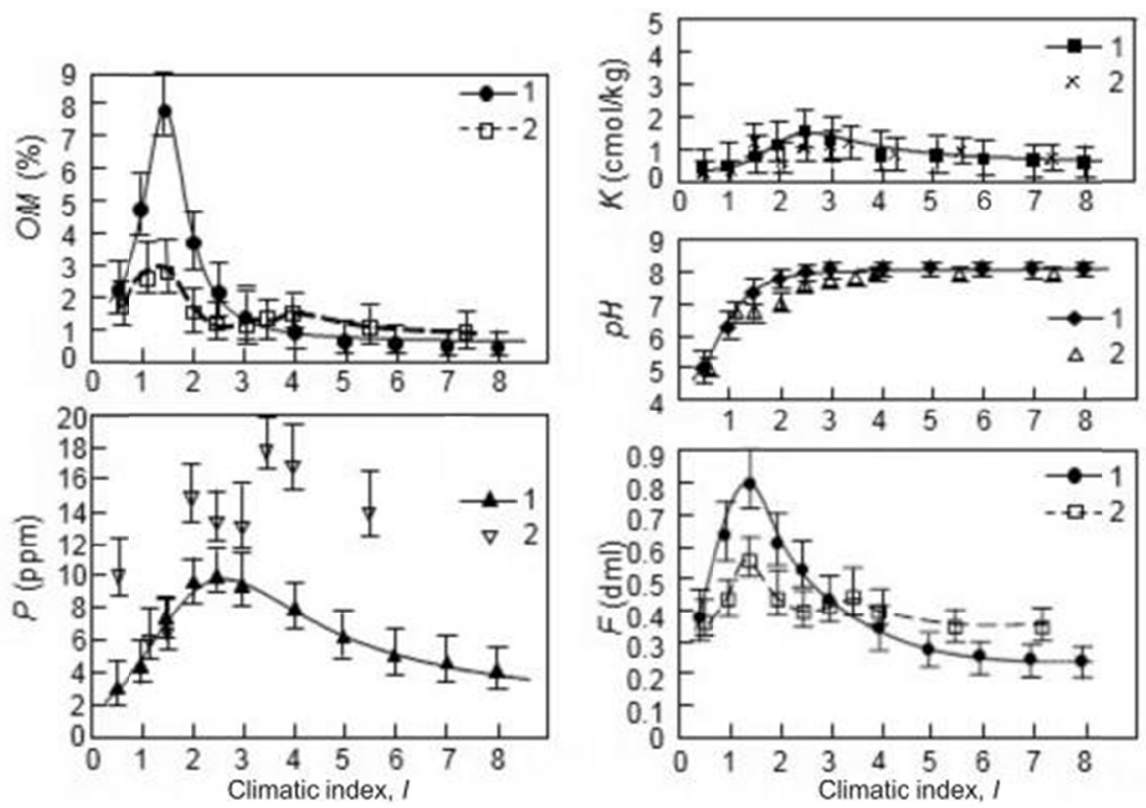

Figure 2. Dependence of the regional modal values of soil fertility upon the climatic index $I$ for non-irrigated virgin soils (1) and long-term freshwater irrigated soils (2) in Mexico. $F$ is calculated as a dimensionless integral fertility index. Surface slopes are less than $1 \%$

In order to explain the possible reasons for the change in organic matter content in irrigated soils, using bibliographic data we assessed plant biomass production, litter and the processes of humification and mineralization of organic matter and its leaching under irrigation for the climatic, irrigation and agricultural conditions and soils typical for the lands analyzed (Volobuev, 1974; Mathieu \& Lozet, 2011). Results showed that a mean annual intensity of water percolation through the soil profile $(q)$ plays a significant role in reducing organic matter (Aidarov et al., 2012; Aidarov \& Nikolskii-Gavrilov, 2013). When $q \leq 0.2 I r$, organic matter content in irrigated soils changes little over time. Yet, when $q$ is much greater than $0.2 I r$, the content of organic matter in long-term freshwater irrigated soils can decrease with increasing $q$.

The content and availability of mineral nutrients depend on the content and composition of organic matter and soil $p H$. When mineral fertilizers are applied at high doses (more than $250-300 \mathrm{~kg} \mathrm{ha}^{-1} \mathrm{year}^{-1}$ ), they have a noticeable effect on soil chemical properties and organic matter composition (Aidarov, 1985). The mean annual doses of nitrogen and phosphate fertilizers on irrigated lands in Mexico as a rule are more than 250-300 $\mathrm{kg} \mathrm{ha}^{-1} \mathrm{year}^{-1}$. Potassium fertilizers usually are not applied (Fertimex, 1987). Application of such doses should be accompanied by a weak decrease in the $p H$ of soils and changes in the composition of organic matter, its solubility and mobility.

According to Palacios and Nikolskii (1995), Semarnat-Cna-Imta (1998), CONAGUA (2008), and Semarnat-Cna (2011), the $q$ values on furrow and border strip irrigated flatlands with corn and wheat in humid $(1>I \geq 0.4)$, semi-humid $(2>I \geq 1)$, semi-arid $(3.5>I \geq 2)$ and arid $(8 \geq I>3.5)$ zones are, on average, $(0.5-0.7) I r,(0.3-0.4) I r$, (0.2-0.3) $I r$ and (0.1-0.2) $I r$, respectively, taking into account differences of hydrophysical soil properties, lengths of furrows and border strips. The change in water percolation, $q$, through the soil profile may explain the distribution of organic matter content in Figure 2.

Our comparison among modal values of organic matter content in rain-fed soils with corn and wheat cultivation and in virgin soils within geomorphologically homogeneous groups and located on lands with slopes less than $1 \%$ did not show statistically significant differences among climatic zones in Mexico (Nikol'skii et al., 2010). The difference in organic matter content in irrigated and virgin soils (Figure 2) is associated mainly with irrigation, with much less water flow in soils than with long-term mineral fertilization and crop and soil management. The regional values of exchangeable potassium and $p H$ in rain-fed and virgin soils also did not show statistically significant differences.

The cation exchange capacity $(C E C)$ of irrigated soils in semi-arid, semi-humid and humid zones (where $0.4<I<$ 2 ) is less than for virgin soils, especially in zones where $1<I<2$ (Figure 3). In irrigated soils of arid zones (where 
$I>3.5) C E C$ is higher in comparison with virgin soils. Analysis of the change in $C E C$ shows that with relatively stable silt and clay contents in irrigated and virgin soils, it is proportional to the change in organic matter content.
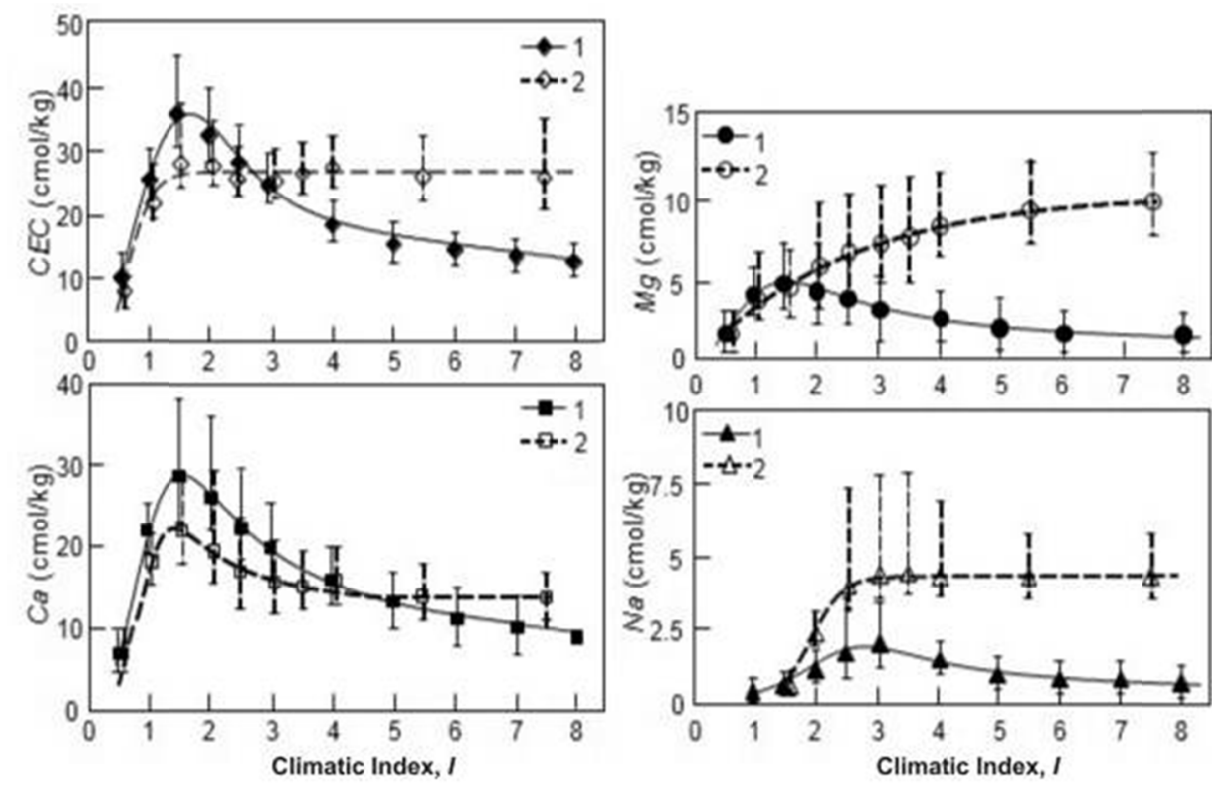

Figure 3. Dependence of the regional modal values of cation exchange capacity, $C E C$, and exchangeable cations upon the climatic index $I$ for non-irrigated virgin soils (1) and long-term freshwater irrigated soils (2) in Mexico.

Surface slopes are less than $1 \%$

In irrigated soils there is a significant change in the composition of the soil exchange complex. In humid and semi-humid zones (where $I<1.5$ ) a reduction in $\mathrm{Ca}, \mathrm{Na}$ and $\mathrm{Mg}$ is observed (Figure 3). In soils of semi-arid areas and zones where $1.5<I<5$, there is a reduction in $\mathrm{Ca}$ and an increase in $\mathrm{Na}$ and $\mathrm{Mg}$. In extra-arid conditions (when $I>5$ ), an accumulation of $N a$ and $M g$ in the soil exchange complex takes place, as well as a relatively small increase in exchangeable $\mathrm{Ca}$. The content of exchangeable $K$ in irrigated soils from all analyzed climatic zones is indistinguishable from that in virgin soils.

The observed changes in cation composition of the exchange complex were analyzed using numerical experiments and mathematical models which simulate leaching conditions on irrigated lands in some selected sites. The models consider the processes of hydrodynamic dispersion, convection transport, isotherms of adsorption of exchangeable cations of $\mathrm{Ca}, \mathrm{Na}, \mathrm{Mg}$ and $\mathrm{K}$, their dissolution, chemical composition of irrigation water and intensity of water percolation through the soil profile, as well as movement of the anions $\mathrm{Cl}^{-} \mathrm{CO}_{3}{ }^{2-}, \mathrm{HCO}_{3}{ }^{-}$and $\mathrm{SO}_{4}{ }^{2-}$ (Aidarov et al., 2012). Virgin and irrigated sites with slopes less than 1\%, with the same types of soil sand the same texture and climatic conditions were selected. The known properties of virgin soils were considered in the calculations as the initial properties of irrigated soils for the calculation of their possible future change with irrigation.

The dispersivity, as a hydrodynamic dispersion parameter and equilibrium isotherms were determined considering soil textures; $C E C$ values and charges of absorbed ions in soil solution were assessed using bibliographical data (Aidarov, 1985; Aidarov et al., 2012; Bresler et al., 1982; Amrhein and Suarez, 1991; Leij and van Genuchten, 1999; Raymundo-Raymundo et al., 2012). The exchange constants for the cation pairs $\mathrm{Na}-\mathrm{Ca}, \mathrm{Na}-\mathrm{Mg}$ and $\mathrm{Na}-\mathrm{K}$ were determined depending on the $C E C$ and the charge of absorbed ions in soil solution (Bresler et al., 1982; Aidarov, 1985; Frenkel \& Meiri, 1985; Ryzhova, 1987; Amrhein \& Suarez, 1991; Aidarov et al., 2012). It was assumed that among the $\mathrm{Ca}, \mathrm{Na}, \mathrm{Mg}$ and $\mathrm{K}$ in soil solution and in the $C E C$ there was equilibrium.

The calculations showed that in the upper soil layer $(0-20 \mathrm{~cm})$ in humid and semi-humid climates where $I<1.5$ and water percolation through the soil profile has the intensity $q \cong(0.4-0.7) I r$, the concentration and composition of exchangeable cations in soil solution should be similar to the irrigation water, and the cation composition in irrigated and rain-fed soils should also be similar, considering a low concentration of irrigation water. In semi-humid and semi-arid climatic conditions where $1.5<I<3$ and with irrigation $q=(0.2-0.3) I r$, the $C E C$ value and exchangeable $\mathrm{Ca}$ content in irrigated soil can be nearly $25 \%$ less and the exchangeable $\mathrm{Mg}$ and $\mathrm{Na}$ contents 
between 1.5-2 times more than in the same soil under rain-fed conditions. In arid conditions, where $I>3.5$ and with irrigation $q=(0.1-0.2) I r$, the $C E C$ value can be nearly 2 times more, exchangeable $C a$ content $10-20 \%$ more and exchangeable $\mathrm{Na}$ and $\mathrm{Mg}$ contents about 5 times more than under rain-fed conditions.

Numerical experiment results also showed that use of the SAR in prediction of soil sodicity underestimates $\mathrm{Na}$ content in the exchange complex. Therefore, in order to assess the composition of the $C E C$ it is necessary, in addition to the $S A R$, to consider the exchangeable $\mathrm{Ca}, \mathrm{Na}, \mathrm{Mg}$ and $\mathrm{K}$ in the irrigation water. Detailed description of the methodology and results of the calculations are provided in Aidarov et al. (2012), and Aidarov and Nikolskii-Gavrilov (2013).

Thus, the intensity of water percolation through the soil profile is an important indicator for the conservation of soil organic matter and it should be considered in irrigation. In order to prevent deterioration of irrigated soil fertility, the irrigation water loss, $q$, related with percolation through the soil profile should be reduced by at least $20 \%$ of the mean annual net irrigation depth.

Considering the deep water table position on analyzed irrigated lands, and the results of the previous calculations, the reduction of irrigation water loss due to water percolation, $q$, should not cause adverse effects on soil salinity or sodicity.

Changing the $p H$ of irrigated soils is consistent with the change in composition of soil solutions. We assessed $p H$ values depending on the calcite content in soil solution on analyzed irrigated lands (Aidarov et al., 2012; Aidarov \& Nikolskii-Gavrilov, 2013). In irrigated soils of climatic zones where $I<1.5$ and with intensive soil leaching, the composition of soil solutions corresponds to the chemical composition of irrigation water and the soil has $p H \cong 5-6$. In more arid regions, where $I>1.5$, the $p H$ of irrigated soils increases positively with the concentration of the soil solution and reaches a maximum value of $p H \cong 8$ when the concentration of the soil solution is about 2 times more than the irrigation water. This is explained by the change in calcite equilibrium due to saturation of the soil solution when there is equilibrium between the content of calcite in irrigation water and in soil solution.

A significant increase in the available phosphorous content in irrigated soils occurs in all climatic zones (INEGI, 2004; FAO, 2006; Krasilnikov et al., 2011). The maximum content of available phosphorus is observed in soils with $p H=7-8$ located in arid zones where $I>3$. With the decrease in $p H$, the content of available phosphorus is less, especially when $p H=5-6$. This is related not only with the solubility of phosphates depending on $p H$, but also with the content of organic matter in the soil. The low solubility of phosphates and high annual doses of phosphate fertilizers on irrigated lands are accompanied by the gradual accumulation of phosphorus in soils. The doses of phosphate fertilizers on irrigated lands in different climatic zones are: $100-170 \mathrm{~kg} \mathrm{ha}^{-1}$ of active substance in regions where $I<1 ; 60-80 \mathrm{~kg} \mathrm{ha}^{-1}$ where $1<I \leq 2 ; 80-120 \mathrm{~kg} \mathrm{ha}^{-1}$ where $2<I \leq 3.5 ; 120-160 \mathrm{~kg} \mathrm{ha}^{-1}$ where $3.5<$ $I \leq 5 ; 80-140 \mathrm{~kg} \mathrm{ha}^{-1}$ where $5<I \leq 6.5$, and $140-180 \mathrm{~kg} \mathrm{ha}^{-1}$ where $6.5<I \leq 8$ (Fertimex, 1987).

For a more accurate analysis of the impact of long-term freshwater irrigation on soil fertility, it would be useful to compare the graphs of agrochemical soil property dependence on the climatic index, $I$, mentioned in Figures 2 and 3 , with similar graphs for other crops having less water consumption than corn and wheat. However, it is difficult to realize such analyses because of the lack of data on irrigated soil properties with different crops. As well, irrigated crops with relatively low water consumption are almost never found in Mexico in the climatic zones with $I<3$, where the soil fertility under irrigated corn and wheat is less than for virgin soils.

Considering the observed deterioration of soil fertility under long-term freshwater furrow and border strip irrigation in semi-arid, semi-humid and humid tropical zones of Mexico, it can be assumed that for the conservation of soil as a natural resource it would be appropriate to reduce the mean annual irrigation water loss to deep percolation through the soil profile by at least $20 \%$ of the mean annual net irrigation depth, or less than 200 $\mathrm{mm}$ per year. This can be achieved by improving furrow and border strip irrigation technology, application of sprinklers, microsprinklers or drip irrigation (where possible) and conservation tillage. In humid tropical conditions with heavy rainfall (up to $2500 \mathrm{~mm}$ per year or more) it is recommended to increase annual water runoff by applying surface drainage in irrigated and rain-fed lands and to improve irrigation technologies. These improvements should significantly reduce annual water percolation and make a contribution to soil fertility conservation.

These measures can reduce water consumption, maintain required soil moisture, improve the efficiency of water and land resource use, conserve soil fertility, increase crop productivity and profitability on agricultural lands and the sustainability of agriculture over the long-term. As well these measures can protect the quality of ground-waters on such land without problems of soil salinity or sodicity. 


\section{Conclusions}

1) The existing practices of furrow and border strip irrigation in Mexico causes positive impact on soil fertility in arid zone and negative impact in semi-arid, semi-humid and humid zones. According to the Figure 2 the fertility of irrigated soils on the basis of a regional scale is less than that of virgin soils, that is, about $10 \%$ in humid zones, where climatic index $I<1 ; 30 \%$ in semi-humid zones $(1 \leq I<2)$ and $20 \%$ in semi-arid zones $(2 \leq I<3.5)$, while the fertility of irrigated soils in arid zones $(I \geq 3.5)$ is about 1.5 more than that of virgin soils.

2) Soil fertility deterioration under long-term freshwater furrow and border strip irrigation in semi-arid, semi-humid and humid zones is due to poor irrigation technology, high mean annual net irrigation depths and, as a consequence, the leaching of organic matter and exchangeable calcium.

3) To prevent deterioration of soil fertility it is recommended to reduce water percolation through the soil profile. This can be accomplished through improvements in furrow and border strip irrigation technology by using shorter furrows and border strips, using sprinklers, microsprinklers, drip irrigation (where possible) and conservation tillage. The final decision should depend on the specific local conditions of each irrigated plot. These measures also protect the quality of groundwaters on lands where there is no problem with soil salinity or sodicity.

4) The improvement of irrigation technology can reduce water consumption, improve the efficiency of water and land resource use, increase productivity and profitability of agricultural lands and the sustainability of agriculture over the long-term.

5) Under humid conditions with heavy rainfall it is recommended to increase annual water runoff by applying surface drainage and improving irrigation technologies. This measure should significantly reduce water percolation through the soil and contribute to soil fertility conservation and the protection of the quality of subsurface drainage waters where such drainage is applied.

\section{Acknowledgements}

To Colegio de Postgraduados, Campus Montecillo and Campus Veracruz (LPI-8 Impacto y Mitigacion del Cambio Climatico) for financial support. Thanks also to Ing. Juan Manuel Hernández Pérez for assistance in the preparation of some figures.

\section{References}

Aidarov, I. P. (1985). Regularities in Water, Salt and Fertility Regimes of Irrigated Soils, Publ. Agropromizdat, Moscow, USSR [in Russian].

Aidarov, I. P., Korolkova, T. P., \& Korolkov, A. I. (2012). Prevention and Control of Salinization and Sodification of Irrigated Lands. Publ. MGUP, Moscow, Russia [in Russian].

Aidarov, I. P., Nikolskii-Gavrilov, I. (2013). Modelling and its application for interpretation of soil quality. In B. Lucke, R. Baumler, \& M. Schmidt (Eds.), Soils, Paleosols and Sediments as Archives of Environmental Change. Publ. Franconian Geograph. Soc., Germany (in press).

Alguacil del Mar, M., Torrecillas E., Torres P., Garcia-Orenes F., \& Roldan, A. (2012). Long-term effects of irrigation with waste water on soil fungi diversity and microbial activities: the implications for agroecosystem resilience. PLoS ONE, 7(10). http://dx.doi.org/10.1371/journal.pone.0047680

Amrhein, C., \& Suarez, D. L. (1991). Sodium-calcium exchange with anion exclusion and weathering corrections. Soil Science Society of America Journal, 59 55, http://dx.doi.org/10.2136/sssaj1991.03615995005500030010x

Artigao, A., Ortega, J. F., Tarjuelo, J. M., \& Juan, J. A. (2002). The impact of irrigation application upon soil physical degradation in Castilla-La Mancha (Spain). Advances in Geoecology, 35, 83-90.

Baldock, D., Caraveli, H., Dwyer, J., Einschutz, S., Petersen, J. E., Sumpsi-Vinas, J., \& Varela-Ortega, C. (2000). The Environmental Impacts of Irrigation in the European Union. Institute for European Environmental Policy, London, UK.

Bresler, E., McNeal, B. L., \& Carter, D. L. (1982). Saline and Sodic Soils. Berlin, Germany: Springer Publ. http://dx.doi.org/10.1007/978-3-642-68324-4

Budyko, M. I. (1977). Global Ecology. Nauka Publ., Moscow, Russia [in Russian].

Buol, S. W., Hole, F. D., \& McCracken, R. J. (1990). Génesis y Clasificación de Suelo. México.

CONAGUA. (2008). Estadísticas de Agua en los Distritos de Riego. Publ. SEMARNAT. 
CONAGUA. (2009). Integracion de Planes de Riego Autorizados para el Ciclo Agrícola 2008-2009. Publ. CONAGUA, México.

CONAGUA. (2012). Propiedades de Suelos de los Distritos de Riego. Archivos de los Distritos de Riego. Publ. CONAGUA, México.

De la Pena, I. (1996). Salinidad y drenaje en la región noroeste en marco nacional. Problemática y soluciones. Publ. CNA, Sonora, México.

De la Pena-De la Torre, I., \& Llerena-Villalpando, F. A. (2001). Manual de Uso y Manejo de Agua de Riego. Publ. UACh-CONAGUA, México.

Dokuchaev, V. V. (1899). Teachings on Zones of Nature. The Horizontal and Vertical Zones. Publ. Russian Soc. of Naturalists, Moscow, Russia [in Russian].

FAO. (2006). World Reference Base for Soil Resources. World Soil Res. Rep. No. 103. Publ. IUSS Working Group WRB, Rome, Italy.

Fertimex. (1987). Guia Nacional de Fertilizacion y Combate de Plagas. Publ. SARH, México.

Frenkel, H., \& Meiri, A. (Eds.). (1985). Soil Salinity: Two Decades of Research in Irrigated Agriculture. Publ. Van Nostrand Reinhold Co., New York, USA.

Grigoriev, A. A. (1954). Geographical zonification of nature in the world. Izvestia AN SSSR, Series Geography, No. 5, 6 [in Russian].

Hyams, D. A. (2012). Curve Fitting System for Windows (version 1.40). Retrieved from $\mathrm{http}: / /$ www.curveexpert.net/curveexpert-basic

IMTA. (2006). Extractor Rápido de Información Climatológico de Mexico ERIC III. Base de datos en CD, v. 1.0. Ed. CNA-IMTA, México.

INEGI. (1988). Atlas Nacional del Medio Fisico. Instituto Nacional de Estadística, Geografía e Informática. Carta Edafológica. Publ. INEGI. Aguascalientes, México.

INEGI. (2004). Conjunto de las Cartas de Topografia, Geología, Uso de Suelo y Edafología, de la República Mexicana. Publ. INEGI, Aguascalientes, México.

Jenny, H. (1941). Factors of Soil Formation. Publ. McGraw-Hill, New York, USA.

Koster, R. D., \& Suarez, M. J. (1999). A simple framework for examining the interannual variability of land $\begin{array}{lllll}\text { surface moisture fluxes. Journal of Climate, 12, 1911-1917. } & \text {. }\end{array}$ http://dx.doi.org/10.1175/1520-0442(1999)012<1911:ASFFET>2.0.CO;2

Krasilnikov, P., Jimenez-Nava, F. J., Reyna-Trujillo, T., \& Garcia-Calderon, N. E. (Eds.). (2011). Geografia de Suelos de México (Soil Geography of Mexico), vol. I, Publ. UNAM, México.

Leij, F. J., Van Genuchten, M. T., Skaggs, R. W., \& Schilfgaarde, J. V. (1999). Principles of solute transport. Agricultural Drainage, 331-359.

Mathieu, C., \& Lozet, J. (2011). Dictionnaire Encyclop'edique de Science du Sol. France.

Mekonnen, G., Enyew, A., \& Asmare, A. (2011). Impacts of irrigation on soil characteristics of selected irrigation schemes in the Upper Blue Nile. In A. M. Melesse (Ed.), Nile River Basin. Hydrology, Climate and Water Use. Springer Science+Business Media Publ., London, UK - New York, USA.

Nikol'skii, Y. N., Castillo-Alvarez, M., Bakhlaeva, O. S., Gama-Castro, J., \& Landeros-Sánchez, C. (2010). Assessing the effect of possible global climate changes on the fertility of Mexican soils and the prediction of crop yields. Eurasian Soil Science, 43, 985-992. http://dx.doi.org/10.1134/S106422931009005X

Oriola, E.O. (2005). Effects of irrigation on soils of a sub-humid part of Kwara state, Nigeria. Centrepoint (Science Edition), 12, 52-62.

Palacios, O. V., \& Nikolskii, Y. N. (1995). Guia computarizada del drenaje parcelario de distritos de riego. México.

Pegov, S. A., \& Khomyakov, P. M. (1991). Modeling of the Development of Ecological Systems. Publ. Gidrometeoizdat, Leningrad, USSR [in Russian].

Raymundo-Raymundo, E., Nikolskii, Y. N., Guber, A. K., \& Landeros-Sánchez, C. (2012). Adequacy of transport parameters obtained in soil column experiments for selected chemicals. Eurasian Soil Science, 45, 675-683. http://dx.doi.org/10.1134/S106422931207006X 
Redly, M., \& Utkaeva, V. F. (2005). Kinds of Chemical Amelioration. In Agricultural land improvement: Amelioration and Reclamation - Vol. II. Encyclopedia of Life Support Systems. Retrieved from http://www.eolss.net

Ryzhova, I. M. (1987). Mathematical modelling of soil processes. MGU Publ., Moscow, Russia (in Russian).

Schjonning, P., Elmholt, S., \& Christensen, B. T. (Eds.). (2004). Managing Soil Quality: Challenges in Modern Agriculture. CABI Publ., Wallingford, UK; Cambridge, USA. http://dx.doi.org/10.1079/9780851996714.0000

SEMARNAT. (2005). Informe de la Situación del Medio Ambiente en México. Compendió de Estadisticas Ambientales. Publ. SEMARNAT, Mexico. Retrieved from http://www.sendspace.com/file/hu113s

SEMARNAT-CNA. (2011). Estadísticas del Agua en México. México.

SEMARNAT-CNA-IMTA. (1998). Manual de Diseño e Instalacion de Drenaje Parcelario en Zonas Aridas y Semi-Aridas Bajo Riego. Publ. CNA-IMTA, México.

SEMARNAT-CP. (2002). Evaluacion de la Degradacion del Suelo Causada por el Hombre en la República Mexicana. Memoria Nacional. Publ. Diamante, Edo. de México, México.

Skaggs, R. W., van Shilfgaarde, J. (Eds.). (1999). Agricultural Drainage. Agronomy Publ., 38, Madison, Wisconsin, USA.

SURFER 8. (2000). Contouring and 3D Surface Mapping for Scientists and Engineers. Golden Software, Inc., Colorado, USA.

Venables, W. N., \& Ripley, B. D. (1997). Modern Applied Statistics with S-PLUS. Springer-Verlag Inc., N.Y., USA. http://dx.doi.org/10.1007/978-1-4757-2719-7

Volobuev, V. R. (1974). Introduction into the Energy of Soil Formation. Nauka Publ., Moscow, USSR [in Russian].

\section{Copyrights}

Copyright for this article is retained by the author(s), with first publication rights granted to the journal.

This is an open-access article distributed under the terms and conditions of the Creative Commons Attribution license (http://creativecommons.org/licenses/by/3.0/). 